\title{
The discriminative power in determining genetic diversity of Escherichia coli isolates: Comparing ERIC- PCR with AFLP
}

\author{
Luka FAJS, Mateja JELEN, Maja BORIĆ, Tanja ĐAPA, Darja ŽGUR-BERTOK and Marjanca \\ STARČIČ ERJAVEC*
}

Department of Biology, Biotechnical Faculty, University of Ljubljana, Večna pot 111, SI-1000 Ljubljana, Slovenia.

Accepted 26 April, 2013

\begin{abstract}
This present study was performed to investigate genetic diversity of Escherichia coli isolates from healthy cattle while comparing two methods namely, PCR assay for enterobacterial repetitive intergenic consensus sequences (ERIC-PCR) and amplified fragment length polymorphism (AFLP). Our study showed that ERIC-PCR is an appropriate/efficient method for determining diversity of $E$. coli, providing results comparable to those obtained by AFLP.
\end{abstract}

Key words: Escherichia coli, diversity, cattle, amplified fragment length polymorphism (AFLP), PCR assay for enterobacterial repetitive intergenic consensus sequences (ERIC-PCR).

\section{INTRODUCTION}

Escherichia coli strains are an important component of the intestinal microbiota of humans and other warm blooded animals. Nevertheless, E. coli strains that possess specific virulence factors can be pathogenic and instigate intestinal and extraintestinal infections causing significant morbidity and mortality (Kaper et al., 2004). The ability to perform epidemiological investigations, to determine the primary sources of bacterial contamination, is important for public health care. A number of methods are available for bacterial source tracking and to determine the distribution of pathogenic isolates: i) methods based on restriction analysis of bacterial DNA; ii) polymerase chain reaction (PCR) amplification of particular genetic targets as well as; iii) methods based on the identification of DNA sequence polymorphisms (Foley et al., 2009). The genetic diversity of $E$. coli populations is determined mainly by analysing amplified fragment length polymorphisms (AFLP) or employing pulsed-field gel electrophoresis (PFGE); because these methods require specific equipment, which are costly and time consuming, they are not suitable for resource-limited settings. On the other hand, ERIC-PCR is a typing method that is relatively inexpensive, less time consuming and therefore easy to implement in such settings.

The aim of our study was to determine the genetic diversity of $E$. coli from faeces of healthy cattle by employing ERIC-PCR and AFLP and to compare the efficacy of both methods in clonal type discrimination. To our knowledge, this study is the first to compare the efficacy of ERIC-PCR and AFLP to assess genetic diversity among $E$. coli isolates.

\section{MATERIALS AND METHODS}

Sampling and identification of bacterial strains

Fecal samples were collected from 12 cows and 7 calves from 5 farms in the vicinity of Ljubljana, Slovenia between December 20, 2007 and April 13, 2009. Samples were inoculated on-site directly 
Table 1. Distribution of clonal types of $E$. coli isolated from healthy cattle as determined by ERIC-PCR.

\begin{tabular}{lll}
\hline Farm (Stable) & Animal & Clonal type number based on ERIC-PCR results \\
\hline \multirow{4}{*}{ Farm 1 } & Cow 1 & 1,2 \\
& Cow 2 & 3 \\
& Calve 1 & 4 \\
& Calve 2 & 4,5 \\
Farm 2 & Cow 3 & 6,7 \\
& Cow 4 & 8,9 \\
& Calve 3 & 10 \\
Farm 3 & Calve 4 & 10,11 \\
& Calve 5 & 10,12 \\
& Cow 5 & 13 \\
Farm 4 (1) & Cow 6 & 14 \\
& Cow 7 & 15,16 \\
Farm 4 (2) & Cow 8 & $17,18,19$ \\
& Cow 9 & $20,21,22$ \\
Farm 4 (3) & Cow 10 & 23 \\
& Cow 11 & 24,25 \\
Farm 5 & Cow 12 & 26 \\
\hline
\end{tabular}

onto MacConkey plates and transferred to the laboratory where they were incubated overnight at $37^{\circ} \mathrm{C}$. Colonies expressing a lactose fermenting phenotype on MacConkey plates were further tested with four biochemical tests (Indole, Methyl red, VogesProskauer, Citrate) and plated onto EMB plates. From each animal sample, five colonies, identified as $E$. coli were further analysed. In total, $95 \mathrm{E}$. coli isolates were included in the study.

\section{ERIC-PCR profiling}

DNA extraction for ERIC-PCR profiling was performed with lysis of bacterial isolates, according to Le Bouguenec et al. (1992). ERICPCR was performed by modification of a method described by Versalovic et al. (1991). Samples $(10 \mu \mathrm{l})$ were amplified in a $50 \mu \mathrm{l}$ reaction mixture containing $10 \mathrm{mM}$ deoxynucleoside triphosphates, $2.5 \mathrm{mM} \mathrm{MgCl}$, 1× Taq Buffer without $\mathrm{KCl}$ (Fermentas, Vilnius, Lithuania), $5 \mathrm{U} / \mu \mathrm{l}$ of Taq DNA polymerase (Fermentas, Vilnius, Lithuania) and $0.4 \mu \mathrm{M}$ of each primer, ERIC1R (5'ATGTAAGCTCCTGGGGATTCAC-3') and ERIC2 (5'AAGTAAGTGACTGGGGTGAGCG-3'). PCR amplification conditions were as follows: initial denaturation at $94^{\circ} \mathrm{C}$ for $4 \mathrm{~min}$, followed by 35 cycles of denaturation at $94^{\circ} \mathrm{C}$ for $30 \mathrm{~s}$, annealing at $40^{\circ} \mathrm{C}$ for $15 \mathrm{~s}$ and elongation at $72^{\circ} \mathrm{C}$ for $5 \mathrm{~min}$. A single final elongation step was performed at $72^{\circ} \mathrm{C}$ for $7 \mathrm{~min}$. The ERIC-PCR profiles, following agarose gel electrophoresis, were determined manually. To obtain reliable results, ERIC-PCR profiling was performed at least twice for each isolate. E. coli isolates that exhibited the same ERIC-PCR profile were considered as the same clonal type.

\section{AFLP-profiling}

For the AFLP, DNA was extracted using phenol and chloroform as previously described by Wilson (1992). AFLP was performed essentially as described by Vos et al. (1995). Briefly, bacterial DNA was digested with EcoRI and Msel and subsequently, adapters were ligated to the ends of the DNA fragments. A selection of the DNA fragments was amplified with a primer labelled with a D3 fluorescent dye (Beckman, Woerden, The Netherlands) and a selective $A$ base as overhang. The amplified fragments were separated by capillary electrophoresis on a Beckman CEQ8000 sequencer (Beckman, Woerden, The Netherlands). AFLP fingerprints were analyzed using Bionumerics® software (Applied Maths, Sint-Martens-Latem, Belgium). Similarity between the fingerprints was determined using the Dice coefficient and dendrograms were generated by the unweighted pair group method with arithmetic mean analysis (UPGMA). Isolates with a Dice coefficient greater than $97 \%$ were considered as the same clonal type.

\section{RESULTS AND DISCUSSION}

ERIC-PCR was performed on all 95 isolates. ERIC-PCR produced profiles with bands ranging from less than 250 bp to approximately $3000 \mathrm{bp}$. Based on analysis of ERICPCR profiles, the isolates were grouped into 32 clonal types. On average, two E. coli clonal types were present in each animal (Table 1). A representative gel with 


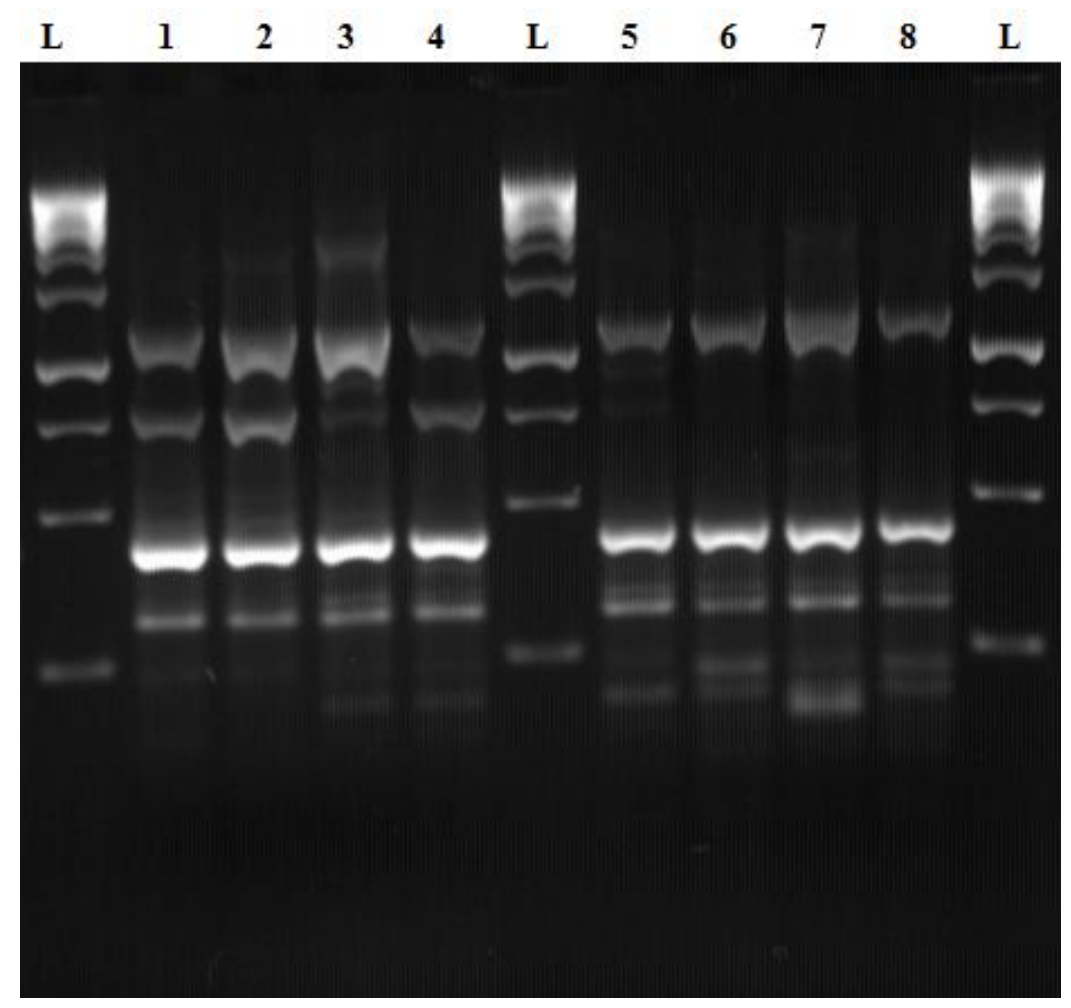

Figure 1. Agarose gel electrophoresis of ERIC-PCR products. ERIC-PCR products were analysed on a $1.5 \%$ agarose gel. $L$ - GeneRuler ${ }^{T M} 1 \mathrm{~kb}$ DNA ladder (Fermentas, St. Leon-Rot, Germany); 1 - ERIC-PCR profile of isolate 82; 2 - ERIC-PCR profile of isolate 83; 3 - ERIC-PCR profile of isolate 69; 4 - ERICPCR profile of isolate $51 ; 5$ - ERIC-PCR profile of isolate 2; 6 - ERIC-PCR profile of isolate 9; 7 - ERIC-PCR profile of isolate 30; 8 - ERIC-PCR profile of isolate 10 . Isolates numbers 82 and 83 exhibited the same ERIC-PCR profile, as well as isolates number 9 and 10 . All other isolates exhibited distinct ERICPCR profiles.

ERIC-PCR profiles is shown in Figure 1. AFLP was performed on 26 isolates representing 25 clonal types, as determined by ERIC-PCR. Two E. coli strains, ATCC 25922 and 35218 were used as outgroup in the dendrogram. Isolates number 1 and 4,45 and 47,11 and 51,34 and 56, 61 and 65, 66 and 69, 73 and 74, exhibited similarity greater than $97 \%$ and were therefore considered genetically similar. All other isolates exhibited less than $97 \%$ similarity and were considered genetically distinct. The majority of the isolates that exhibited similarity greater than $97 \%$ were either from the same cow (isolates 61 and 65, 66 and 69, 1 and 4, 73 and 74, respectively), or from the same farm but from different cows (isolates 45 and 47 ).

In only 2 cases were found genetically similar isolates from cows from different farms (51 and 11, 34 and 56, respectively). Based on the AFLP fingerprints, the 26 isolates grouped into 19 groups. The results are shown in Figure 2. The AFLP results obtained in our study, therefore suggest a lower diversity as the 26 isolates tested with AFLP, which represented 25 distinct clonal types based on ERIC-PCR, were identified as 19 different AFLP clonal types. This suggests that ERIC-PCR was more proficient than AFLP in distinguishing different clonal types. Nevertheless, in a previous study, Leung et al. (2004) reported that ERIC-PCR compared to AFLP, exhibited a lower discriminatory power however, the purpose of their study was to compare the ability of the two methods to assign $E$. coli isolates to different host sources (bovine, human and pig). Our ERIC-PCR results revealed that $E$. coli isolates from cattle are genetically very diverse, as also shown previously (Fremaux et al., 2006; Houser et al., 2008; Liebana et al., 2003; Panutdaporn et al., 2004). For example, Panutdaporn et al. (2004) found 14 distinct ERIC-PCR profiles among 49 $E$. coli isolates from healthy cattle. It should be taken into consideration that, in our study, two different principles for determination of clonal types were applied, with ERICPCR, the intention was to keep the cost as low as possible (agarose gel electrophoresis and manual determination of profiles) in contrast to AFLP (capillary electrophoresis and computer analysis of profiles). 


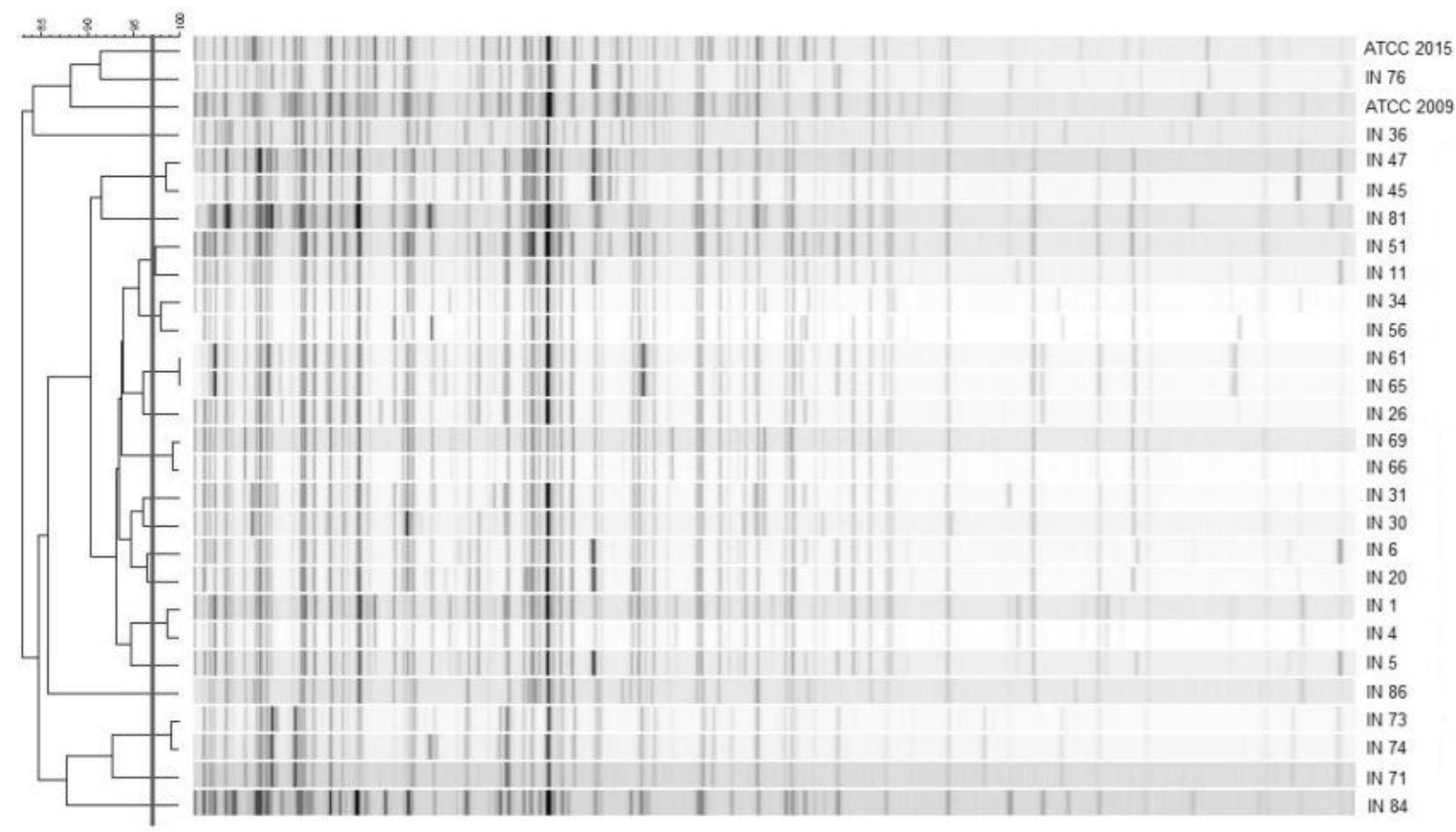

Figure 2. Dendrogram generated with Bionumerics ${ }^{\circledR}$ software showing the AFLP results. Results were analyzed using the Dice coefficient and the unweighted-pair group with arithmetic averages. The thicker vertical line represents a $97 \%$ Dice similarity coefficient. Isolates sharing a similarity greater than $97 \%$ were considered genetically similar. Legend: $\mathrm{IN}=$ isolate number, ATCC = American Type Culture Collection strain.

Our results suggest that both methods are comparably proficient in determining the diversity of $E$. coli populations. To our knowledge, this is the first study to compare the efficacy of ERIC-PCR and AFLP in assessing genetic diversity of $E$. coli. Further studies including a larger number of isolates tested with both methods, ERIC-PCR and AFLP are needed to clearly demonstrate the proficiency of ERIC-PCR for isolate profiling.

\section{ACKNOWLEDGMENT}

This research was financed by Grant P1-0198 from the Slovenian Research Agency (ARRS).

\section{REFERENCES}

Foley SL, Lynne AM, Nayak R (2009). Molecular typing methodologies for microbial source tracking and epidemiological investigations of Gram-negative bacterial foodborne pathogens. Infect. Genet. Evol. 9: 430-440.

Fremaux B, Raynaud S, Beutin L, Rozand CV (2006). Dissemination and persistence of Shiga toxin-producing Escherichia coli (STEC) strains on French dairy farms. Vet. Microbiol. 117:180-191.

Houser BA, Donaldson SC, Padte R, Sawant AA, Debroy C, Jayarao BM (2008). Assessment of phenotypic and genotypic diversity of Escherichia coli shed by healthy lactating dairy cattle. Foodborne Pathog. Dis. 5: 41-51.

Kaper JB, Nataro JP, Mobley HLT (2004). Pathogenic Escherichia coli. Nat. Rev. Microbiol. 2: 123-140.
Le Bouguenec C, Archambaud M, Labigne A (1992). Rapid and specific detection of the pap, afa, and sfa adhesin-encoding operons in uropathogenic Escherichia coli strains by polymerase chain reaction. J. Clin. Microbiol. 30: 1189-1193.

Leung KT, Mackereth R, Tien YC, Topp E (2004). A comparison of AFLP and ERIC-PCR analyses for discriminating Escherichia coli from cattle, pig and human sources. FEMS Microbiol. Ecol. 47: 111119.

Liebana E, Smith RP, Lindsay E, McLaren I, Cassar C, Clifton-Hadley FA, Paiba GA (2003). Genetic diversity among Escherichia coli O157:H7 isolates from bovines living on farms in England and Wales. J. Clin. Microbiol. 41: 3857-3860.

Panutdaporn N, Chongsa-Nguan M, Nair GB, Ramamurthy T, Yamasaki S, Chaisri U, Tongtawe P, Eampokalarp B, Tapchaisri P, Sakolvaree $\mathrm{Y}$, Kurazono H, Thein WB, Hayashi H, Takeda Y, Chaicumpa W (2004). Genotypes and phenotypes of Shiga toxin producingEscherichia coli isolated from healthy cattle in Thailand. J. Infect. 48: 149-160.

Versalovic J, Koeuth T, Lupski JR (1991). Distribution of repetitive DNA sequences in eubacteria and application to fingerprinting of bacterial genomes. Nucleic Acids Res. 19: 6823-6831.

Vos $P$, Hogers R, Bleeker M, Reijans $M$, van de Lee $T$, Hornes $M$, Frijters A, Pot J, Peleman J, Kuiper M, Zabeau M (1995). AFLP: a new technique for DNA fingerprinting. Nucleic Acids Res. 23: 44074414.

Wilson K (1992). Miniprep of bacterial genomic DNA. In Ausubel F M et al. (eds) Short protocols in molecular biology. John Wiley \& Sons, New York, USA, pp. 2.10-2.11. 